\title{
The effectiveness of non-operative treatment in high-grade liver and spleen injury in children
}

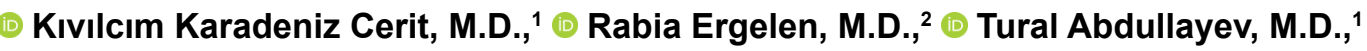

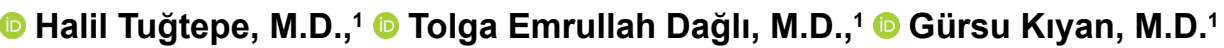

${ }^{1}$ Department of Pediatric Surgery, Marmara University Faculty of Medicine, İstanbul-Turkey

${ }^{2}$ Department of Radiology, Marmara University Faculty of Medicine, İstanbul-Turkey

\begin{abstract}
BACKGROUND: Although a nonoperative treatment approach is preferred for blunt liver and spleen trauma in childhood, there are significant differences between clinics in the algorithms used. The approach to high-grade liver and spleen injury is still controversial, particularly as grade V liver and spleen injuries are not included in the American Pediatric Surgical Association guideline. The aim of this study was to present experience with a non-operative treatment approach to children with high-grade liver and spleen injuries.
\end{abstract}

METHODS: Pediatric patients who were referred to Marmara University Hospital's emergency department between January 2012 and January 2017 due to liver and spleen injury related to blunt abdominal trauma and who were followed up in the clinic were included in the study. The data were analyzed retrospectively in terms of age, sex, type of trauma, degree of organ damage, accompanying organ damage, duration of intensive care unit (ICU) and hospital stay, need for transfusion, and treatment method (operative-nonoperative). Grade I, II, or III organ damage was classified as low-grade, while grade IV and V organ lesions were classified as high-grade.

RESULTS: Of 2800 patients who were diagnosed by radiological imaging with liver and spleen injuries due to blunt abdominal trauma and hospitalized in the clinic, 88 were included in the study. Isolated liver injury was determined in 41 patients, while 39 had an isolated spleen injury, and 8 had injuries to both organs. An accompanying organ injury was observed in 30 (34\%) patients. In all, 83 (94\%) patients underwent non-operative treatment and a surgical approach was required for 5 patients (6\%). Patients with high-grade liver injury had a significantly longer period of hospitalization, duration of ICU stay, and greater transfusion requirement, compared with patients with low-grade liver injury ( $p=0.00 \mathrm{I}, 0.00 \mathrm{I}$, and $<0.00 \mathrm{I}$, respectively). A surgical approach was more common among patients with a highgrade liver injury than for patients with a low-grade injury $(p=0.045)$. There was no significant difference between patients with a high- or low-grade spleen injury in terms of age, sex, duration of hospitalization, duration of ICU stay, transfusion requirement, or accompanying organ injury $(p=0.254,0.739,0.114,0.135,0.057,0.721$, respectively). Similarly, there was no significant difference in terms of non-surgical or surgical treatment approach between the patients with high-grade spleen injury and those with low-grade spleen injury $(p=0.488)$.

CONCLUSION: Non-operative treatment is a feasible treatment method in pediatric patients with a high-grade blunt liver or spleen injury. Nonetheless, pediatric surgeons should bear in mind that patients with high-grade liver damage may require more surgical treatment.

Keywords: Blunt abdominal trauma; liver injury; non-operative management; pediatric trauma; spleen injury.

\section{INTRODUCTION}

Despite the improvements and success in measures undertaken for child safety, trauma is still an important cause of mortality and morbidity during childhood. ${ }^{[1]}$ Although the main cause of death is head trauma in this population, abdominal injuries also affect $10 \%$ to $15 \%$ of children experiencing medical trauma. ${ }^{[2]}$

Cite this article as: Karadeniz Cerit K, Ergelen R, Abdullayev T, Tuğtepe H, Dağlı TE, Kıyan G. The effectiveness of non-operative treatment in high-grade liver and spleen injury in children. Ulus Travma Acil Cerrahi Derg 2018;24:569-574.

Address for correspondence: Kıvılcım Karadeniz Cerit, M.D.

Fevzi Çakmak Mah., Mimar Sinan Cad., No: 4I, Üst Kaynarca, Pendik, İstanbul, Turkey

Tel: +90 216 - 4212222 E-mail: kcerit@yahoo.com

Ulus Travma Acil Cerrahi Derg 2018;24(6):569-574 DOI: 10.5505/tjtes.2018.83573 Submitted: 01.11.2017 Accepted: 16.01.2018 Online: 17.01.2018

Copyright 2018 Turkish Association of Trauma and Emergency Surgery 
Pediatric surgeons have pioneered non-operative management techniques for blunt solid organ injury, and conservative treatment has become the standardized approach in hemodynamically stable patients. Several studies have shown that the rate of surgery performed significantly decreased when pediatric surgeons participated in the evaluation of childhood trauma cases. ${ }^{[3]}$ Non-operative management approaches to blunt liver and spleen trauma in childhood have become preferable; however, there are significant differences between clinics in the algorithms used. Although there are many publications related to non-operative approaches to childhood liver and spleen trauma overall, there are only a few discussing the success of non-operative management in patients with severe liver and spleen injury (Grade IV-V).

The aim of the present study was to present experience with a non-operative management approach to young patients with high-grade blunt liver and spleen injuries.

\section{MATERIALS AND METHODS}

Pediatric patients who were admitted to the emergency department and followed up in the clinic due to a blunt abdominal trauma-induced liver and spleen injuries between January 2012 and January 2017 were included in this study. Data related to age, sex, trauma type, degree of organ injury, associated organ injury, length of intensive care unit (ICU) stay and hospitalization, transfusion requirement, and treatment method (operative vs non-operative) were retrieved from the hospital database and retrospectively analyzed. Grade I, II, and III organ injuries were classified as low-grade, while Grade IV and V organ injuries were classified as high-grade. A written informed consent was obtained for each patient. The present study was approved by the Ethics Committee (09.2017.284) and conducted in accordance with the principles of the Declaration of Helsinki.

A physical examination, evaluation of hemodynamics according to cardiac and saturation monitoring, measurement of hemoglobin and biochemical values as part of the laboratory parameters assessed, and computerized tomography (CT) imaging constitute the initial steps as routine practice in the emergency setting at the hospital. The CT scans used for organ injury grading were performed by a single radiologist (RE) using the classification of the American Association for the Surgery of Trauma. After the initial evaluation, the patients were taken to the ICU or ward, depending on their hemodynamic status. Patients with massive hemorrhage (requiring blood transfusion $>40 \mathrm{~mL} / \mathrm{kg}$ ), and those whose hemodynamic findings did not recover despite fluid and blood transfusion support underwent urgent surgery. A non-operative management decision may be made for patients who are hemodynamically stable after fluid and blood transfusion support. Non-operative management involves close followup of the hemodynamic findings of patient and measurement of hemoglobin values every 4 hours until stabilization. After I week of follow-up in the hospital setting, potential discharge is assessed using repeat ultrasonography. Patients who had a splenectomy were recommended to follow a vaccination schedule (meningococcal and pneumococcal vaccination and penicillin prophylaxis).

\section{Statistical Analysis}

Statistical analysis was performed using IBM SPSS Statistics for Windows, Version 20.0 software (IBM Corp., Armonk, NY, USA). Descriptive statistics were expressed as mean $\pm S D$ for continuous variables and as numbers and percentages for categorical variables. According to the distribution of the variables, an independent samples t-test or the Mann-Whitney $U$ test was used to compare continuous variables. A chisquare test was used to compare categorical variables. An exact test, Pearson's chi-square, Yates correction, and Fisher's exact test were used, as appropriate. A p value of $<0.05$ was considered statistically significant.

\section{RESULTS}

A total of 2,800 general trauma patients who were admitted to the emergency department of Marmara University Hospital during the study period, and 960 patients had an abdominal trauma. Of these, 88 patients who had liver and spleen injuries due to blunt abdominal trauma as assessed with imag-

Table I. Clinical variables of the patients

Age (months, mean $\pm \mathrm{SD}$ )

$105.90 \pm 57.75$

Sex, n (\%)

Male

Female

Type of trauma, $\mathrm{n}(\%)$

Falling from a height

In-car traffic accident

Pedestrian traffic accident

Bicycle/motorcycle accident

Type and degree of injury ( $n$ )

Liver (Low-grade/high-grade)

Spleen (Low-grade/high-grade)

Treatment, n (\%)

Non-operative

Operative

Length of hospitalization (days, mean $\pm S D$ )

Duration of intensive care unit stay

(days, mean $\pm \mathrm{SD}$ )

$2.85 \pm 5.68$

Blood transfusion requirement, $\mathrm{n}(\%)$

Yes

No

Numbers after the decimal point were rounded off in percentages. 

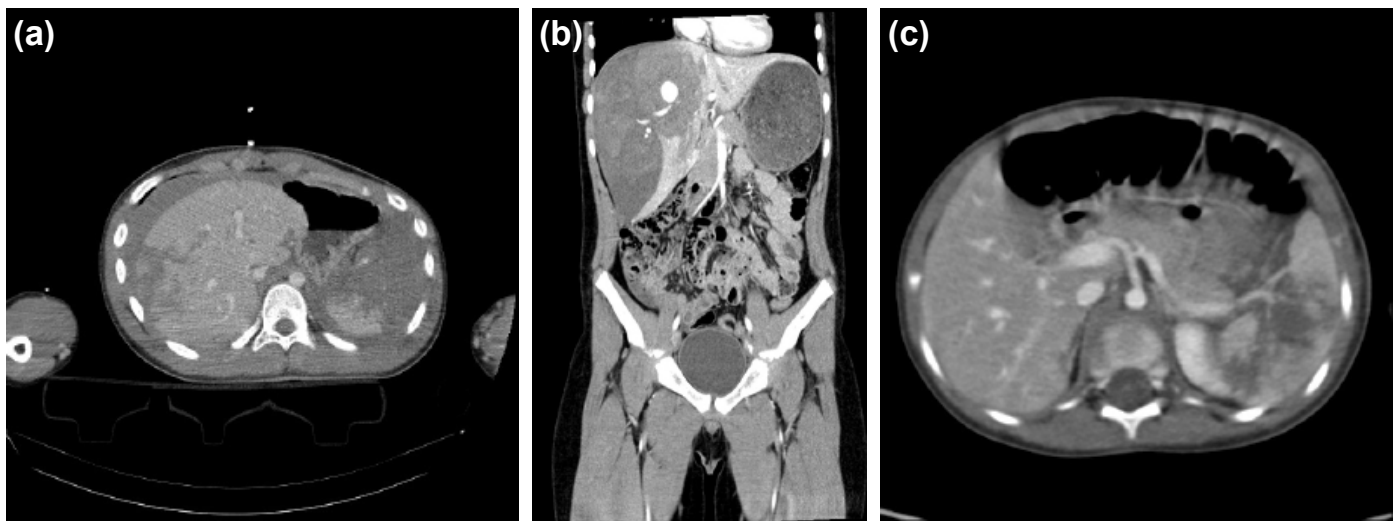

Figure 1. (a) Linear hypodense intraparenchymal grade III laceration with perihepatic fluid and splenic grade V laceration, active bleeding, and perisplenic fluid as seen on a contrast-enhanced axial computed tomography image. (b) Coronal contrast-enhanced computed tomography image revealing a large subscapcular hematoma and active intraparenchymal bleeding, a grade $V$ liver injury. (c) Deep lacerations consistent with a grade IV splenic injury seen on an axial contrast-enhanced computed tomography image.

ing studies and who were hospitalized were included in the study. The clinical data of the patients included in the study are presented in Table I.

Isolated liver injury was observed in 41 patients, isolated spleen injury in 39 patients, and injury in both organs in 8 patients. The patients with injury in both organs were added to the group reflecting the organ with a greater degree of injury (Fig. Ia). A total of 29 high-grade liver injuries (Fig. Ib) and 17 low-grade liver injuries were observed. A total of 21 highgrade spleen injuries (Fig. Ic) and 21 low-grade spleen injuries were recorded. In $34 \%(n=30)$ of the patients, an associated organ injury was present. Thoracic injury was present in 21 (23.9\%) patients, cranial injury in I (I\%) patient, orthopedic injury in I (I\%) patient, kidney injury in I (I\%) patient, and multi-organ injury in $6(6.8 \%)$ patients.

Non-operative management was pursued in 83 patients (94\%), and surgery was indicated in $5(6 \%)$ patients. Among the patients requiring surgery, a splenectomy was performed due to Grade V spleen injury in 2 cases, and packing was performed due to Grade $V$ liver injury in 2 patients. Another patient with Grade $V$ hepatic injury for whom non-operative management was initiated was treated with drainage due to the development of a biloma. Among 2 (2.3\%) non-survivors, $\mathrm{I}$ died in the emergency department due to Grade $\mathrm{V}$ liver injury before the operation, while the other patient, also with Grade $V$ liver injury, died due to disseminated intravascular coagulation after packing was performed. Pleural effusion developed as a complication in 2 patients with Grade $V$ spleen injury, which was treated with chest tube drainage. In I of the patients with Grade $V$ spleen injury who underwent a splenectomy, hemothorax developed and a thoracoscopy was performed, as the lung had not expanded after the insertion of the chest tube.

A comparison of the clinical data for high- and low-grade liver injuries is shown in Table 2. There was no significant difference between the patients with high-grade liver injury and those with low-grade liver injury in terms of age, sex, or associated organ injuries $(p=0.135, p=0.149$ and $p=0.800$, respectively). However, among the patients with high-grade

Table 2. Comparison of clinical variables between high- and low-grade liver injuries

\begin{tabular}{|c|c|c|c|}
\hline Liver injuries & $\begin{array}{l}\text { High-grade } \\
\quad(n=17)\end{array}$ & $\begin{array}{c}\text { Low-grade } \\
\quad(n=29)\end{array}$ & $\mathbf{p}$ \\
\hline Age (months) & $101.29 \pm 58.80$ & $75.5 I \pm 4 I .25$ & $=0.135$ \\
\hline Male/female ratio & $14 / 3$ & $|8 / 1|$ & $=0.149$ \\
\hline Length of hospitalization (days) & $12.82 \pm 8.45$ & $6.27 \pm 3.04$ & $=0.001$ \\
\hline Intensive care unit stay (days) & $5.11 \pm 7.02$ & $1.10 \pm 1.34$ & $=0.001$ \\
\hline Transfusion requirement (yes/no) & $12 / 5$ & $5 / 24$ & $<0.001$ \\
\hline Associated organ injuries (yes/no) & $6 / 9$ & $9 / 16$ & $=0.800$ \\
\hline \multicolumn{4}{|l|}{ Treatment approach } \\
\hline Conservative & 14 & 29 & $=0.045$ \\
\hline Surgery & 3 & 0 & \\
\hline
\end{tabular}


Table 3. Comparison of clinical variables between high- and low-grade spleen injuries

\begin{tabular}{|c|c|c|c|}
\hline Spleen injuries & $\begin{array}{l}\text { High-grade } \\
\qquad(n=2 I)\end{array}$ & $\begin{array}{l}\text { Low-grade } \\
\qquad(n=2 I)\end{array}$ & $\mathbf{p}$ \\
\hline Age (months) & $118.42 \pm 62.73$ & $139.09 \pm 52.43$ & $=0.254$ \\
\hline Male/female ratio & $15 / 6$ & $14 / 7$ & $=0.739$ \\
\hline Length of hospitalization (days) & $14.66 \pm \mid 4.90$ & $9.95 \pm 7.35$ & $=0.114$ \\
\hline Intensive care unit stay (days) & $4.66 \pm 8.96$ & $1.61 \pm 2.06$ & $=0.135$ \\
\hline Transfusion requirement (yes/no) & $11 / 10$ & $5 / 16$ & $=0.057$ \\
\hline Associated organ injuries (yes/no) & $5 / 14$ & $6 / 13$ & $=0.721$ \\
\hline \multicolumn{4}{|l|}{ Treatment approach } \\
\hline Conservative & 19 & 21 & $=0.488$ \\
\hline Surgery & 2 & 0 & \\
\hline
\end{tabular}

liver injury, the length of hospitalization, the duration of ICU stay, and the transfusion requirement were significantly higher than in patients with low-grade liver injury $(p=0.00$ I, $p=0.00 \mathrm{I}$, and $\mathrm{p}<0.00 \mathrm{I}$, respectively). In addition, the patients with high-grade liver injury underwent more surgical interventions than those with low-grade liver injury $(p=0.045)$.

A comparison of the clinical data for the high- and low-grade spleen injuries is shown in Table 3 . There was no significant difference between the high- and low-grade spleen injury groups in terms of age, sex, length of hospitalization, duration of ICU stay, transfusion requirement, or associated organ injuries $(p=0.254, p=0.739, p=0.1 \mid 4, p=0.135, p=0.057$, and $p=0.72 \mathrm{I}$, respectively). Similarly, there was no significant difference in terms of non-surgical or surgical treatment approach between the patients with high-grade spleen injury and those with low-grade spleen injury $(p=0.488)$.

\section{DISCUSSION}

In cases of blunt trauma to the liver and spleen, non-operative management has become an effective treatment approach with low mortality. Repeated clinical evaluations supported by radiological imaging and laboratory analysis constitute the basis of non-operative management, thus preventing unnecessary surgical interventions. ${ }^{[4]}$ The trauma committee of the American Pediatric Surgical Association (APSA) developed guidelines to eliminate differences in the approach to patients with isolated blunt trauma to the liver and spleen and to establish standardization in the approach to these patients. ${ }^{[5,6]}$ In these guidelines, only Grade IV patients are admitted to the ICU, and the length of hospitalization is calculated by adding I day to the determination based on the degree of organ injury as assessed by CT. The fact that the transfusion rate was $2 \%$ to $10 \%$ and the operation rate less than $3 \%$ supported patients with Grade I-III injuries not being followed-up in the ICU. Significant differences were observed in transfusion and operation rates between Grade III-IV patients, suggesting an increase in the clinical severity of those patients. ${ }^{[5]}$
However, since the APSA guideline does not include Grade $V$ blunt liver and spleen injury, the approach to these patients is still controversial. ${ }^{[5,6]}$ St. Peter et al. ${ }^{[7]}$ established a prospective protocol with a shortened hospitalization period and included the category of Grade $\mathrm{V}$ blunt liver and spleen injury. The data of patients with Grade I-V liver and spleen injuries were analyzed retrospectively. Grade I-II patients were hospitalized for I night, while higher grades were hospitalized for 2 nights. After 2 days of hospitalization, they observed that none of the patients without clinical evidence of hemorrhage required surgery. St. Peter et al. ${ }^{[8,9]}$ also presented 2 prospective studies to evaluate the reliability and efficacy of the protocol that they established reducing the length of hospitalization. One night of hospitalization was recommended for Grade I-II patients and 2 nights for those with a more severe classification.

Yang et al. ${ }^{[10]}$ reported their experiences with a non-surgical approach to patients with Grade IV-V liver and spleen injuries. The data revealed that patients with a high-grade liver injury had a significantly longer ICU stay and hospitalization period than those with a similar grade of spleen injury, and that the requirements for transfusion and radiological imaging, and hospital costs were also significantly higher. In our study, the length of hospitalization, the duration of ICU stay, and transfusion requirements were significantly higher for patients with a high-grade liver injury than for those with lowgrade liver injury. Though St. Peter et al. ${ }^{[8,9]}$ recommended an abbreviated bed rest protocol regardless of injury grade, we think that ICU follow-up is important on the first day to perform non-operative management effectively and to correctly determine the timing of surgical intervention, particularly in patients with high-grade liver injury.

Landau et al. ${ }^{\left[{ }^{\prime \prime}\right]}$ presented 22 years of experience in the approach to blunt liver trauma. In the past, due to the belief that a significant liver injury could not heal itself, an aggressive approach and early surgical intervention was considered to be 
the best method. However, they observed that the mortality was high, due to both unnecessary surgeries and difficult surgical techniques. In our study, non-operative management in patients with a liver injury had a success rate of $93 \%$. It was also found that patients with a high-grade liver injury underwent more surgical treatment than those with low-grade liver injury. Therefore, we recommend that it should be taken into account that surgical treatment may be needed more frequently in patients with high-grade liver injury, and that all of the preparations for surgery be completed within the first hour after admission while closely monitoring hemodynamic status.

Furthermore, Davies et al. ${ }^{[12]}$ retrospectively analyzed cases of spleen trauma that were admitted to their clinics during 4 different multi-year time periods. They observed that the length of hospitalization and the rate of transfusion both declined steadily. In the past, these patients were followed-up in the hospital for at least 5 days. Since the implementation of the APSA guideline, the reported length of hospitalization is expected to continue to reflect a decline over the next few years. In our study, non-operative management was successful in $95 \%$ of patients with a spleen injury. In addition, there was no significant difference between high- and low-grade spleen injury patients in terms of the length of hospitalization or duration of ICU unit stay, transfusion requirement, or non-operative or operative treatment approach. It can be concluded that the abbreviated bed rest protocol can be implemented more safely in patients with spleen trauma.

Nance et al. ${ }^{[13]}$ analyzed patients defined as having solid organ injury according to the national trauma database from a 12 year period. The mean time to surgery was 2.4 hours. For $61.7 \%$ of the patients, surgical intervention was performed within the first 3 hours, for $79.4 \%$ it was within the first 6 hours, and for $89.7 \%$ it occurred within the first 24 hours. The rate of surgical intervention was highest in cases with spleen injury (8.7\%), while it was $3.5 \%$ for patients with a liver injury and $3.0 \%$ for those with a kidney injury. According to the patient series, an abdominal operation was performed within the first 24 hours in $90 \%$ of the patients who required surgery. This study also indicated that the probability of nonoperative management failure is $<10 \%$ in patients who do not require surgery within the first 24 hours. In our study, 4 patients with non-operative management failure who underwent surgery were taken into the operation in less than 3 hours. Surgery was not required after 24 hours for any of patients for whom non-operative management was applied. This also supports the abbreviated bed rest protocol recommended by St. Peter, which suggests that I night of bed rest is sufficient for patients with a low-grade spleen or liver injury.

Tataria et al. ${ }^{[14]}$ reviewed patients from a 10-year period who had been treated for blunt abdominal injury. They defined 2 groups: immediate surgery, performed for 58\%; and failed non-operative management, which was initiated in $42 \%$, and due to failure of the treatment, led to surgery $>3$ hours after admission. The authors indicated that there was no significant difference between the groups in terms of mortality rate, duration of ICU stay, length of hospitalization or blood transfusion requirement. These results support the use of non-operative management as initial therapy in patients with blunt spleen and liver trauma. However, close follow-up of the hemodynamic findings of patients is important in this process.

The retrospective design and small sample size are the primary limitations of the present study. Although the power of this study is low due to the small number of patients, the limited number of publications in the literature about nonoperative management success in patients with high-grade (Grade IV-V) liver and spleen injury in childhood increases the value of our research.

Finally, it is important to inform family members of patients about proper bed rest at home in order to shorten the length of hospitalization and ICU stay. In addition to what we have learned from the APSA guidelines and recent studies, further prospective studies are needed in order to develop thorough recommendations that will reduce the length of ICU stay and hospitalization.

\section{Conclusion}

In conclusion, non-operative management is a feasible method for the treatment of patients with high-grade blunt liver and spleen injury. Close follow-up of hemodynamic findings constitutes the basis of this treatment. The surgical approach is necessary in hemodynamically unstable patients; however, this probability decreases to $10 \%$ after 24 hours. Although the APSA guidelines recommend that the length of hospitalization should be determined according to the CT grade of the patient, the hemodynamic status of patients may be a more effective gauge of the length of hospitalization required.

\section{Acknowledgements}

None

Conflict of interest: None declared.

\section{REFERENCES}

1. Falcone RA Jr, Brown RL, Garcia VF. The epidemiology of infant injuries and alarming health disparities. J Pediatr Surg 2007;42:172-7.

2. Gaines BA. Intra-abdominal solid organ injury in children: diagnosis and treatment. J Trauma 2009;67:135-9. [CrossRef]

3. Stylianos S, Ford HR. Outcomes in pediatric trauma care. Semin Pediatr Surg 2008;17:110-5. [CrossRef]

4. Raza M, Abbas Y, Devi V, Prasad KV, Rizk KN, Nair PP. Non operative management of abdominal trauma - a 10 years review. World J Emerg Surg 2013;8:14. [CrossRef]

5. Stylianos S. Evidence-based guidelines for resource utilization in children with isolated spleen or liver injury. The APSA Trauma Committee. J Pediatr Surg 2000;35:164-9. [CrossRef] 
6. Stylianos S. Liver/Spleen Trauma Study Group. Compliance with evidence-based guidelines in children with isolated spleen or liver injury: A prospective study. J Pediatr Surg 2002;37:453-6. [CrossRef]

7. St Peter SD, Keckler SJ, Spilde TL, Holcomb GW 3rd, Ostlie DJ. Justifcation for an abbreviated protocol in the management of blunt spleen and liver injury in children. J Pediatr Surg 2008;43:191-4. [CrossRef]

8. St Peter SD, Sharp SW, Synder CL, Sharp RJ, Andrews WS, Murphy $\mathrm{JP}$ et al. Prospective validation of an abbreviated bedrest protocol in the management of blunt spleen and liver injury in children. J Pediatr Surg 2011;46:173-7. [CrossRef]

9. St Peter SD, Aguayo P, Juang D, Sharp SW, Synder CL, Holcomb GW 3rd, et al. Follow up of prospective validation of an abbreviated bedrest protocol in the management of blunt spleen and liver injury in children.J Pediatr Surg 2013;48:2437-41. [CrossRef]
10. Yang JC, Sharp SW, Ostlie DJ, Holcomb GW 3rd, St Peter SD. Natural history of nonoperative management for grade 4 and 5 liver and spleen injuries in children. J Pediatr Surg 2008;43:2264-7. [CrossRef]

11. Landau A, van As AB, Numanoglu A, Millar AJ, Rode H. Liver injuries in children: The role of selective non-operative management. Injury 2006;37:66-71. [CrossRef]

12. Davies DA, Pearl RH, Ein SH, Langer JC, Wales PW. Management of blunt splenic injury in children: evolution of the nonoperative approach.J Pediatr Surg 2009;44:1005-8. [CrossRef]

13. Nance ML, Holmes JH 4th, Wiebe DJ. Timeline to operative intervention for solid organ injuries in children. J Trauma 2006;61:1389-92.

14. Tataria M, Nance ML, Holmes JH 4th, Miller CC 3rd, Mattix KD, Brown RL et al. Pediatric blunt abdominal injury: age is irrelevant and delayed operation is not detrimental. J Trauma 2007;63:608-14.

\section{ORIJINAL ÇALIŞMA - ÖZET}

\section{Yüksek dereceli karaciğer ve dalak hasarında nonoperatif tedavinin etkinliği \\ Dr. Kıvılcım Karadeniz Cerit, ${ }^{1}$ Dr. Rabia Ergelen, ${ }^{2}$ Dr. Tural Abdullayev, ${ }^{1}$ Dr. Halil Tuğtepe, ${ }^{1}$ Dr. Tolga Emrullah Dağlı, ${ }^{1}$ Dr. Gürsu Kıyan ${ }^{1}$}

${ }^{1}$ Marmara Üniversitesi Tıp Fakültesi, Çocuk Cerrahisi Anabilim Dalı, İstanbul

${ }^{2}$ Marmara Üniversitesi Tıp Fakültesi, Radyoloji Anabilim Dalı, İstanbul

AMAÇ: Her ne kadar çocukluk çağında künt karaciğer ve dalak travmasında nonoperatif tedavi yaklaşımı tercih edilir olsa da, klinikler arasında kullanılan algoritmalarda ciddi farklılıklar bulunmaktadır. Amerikan Pediatrik Cerrahi Birliği (APSA) rehberinin grade $\vee$ karaciğer ve dalak hasarını içermemesi ile birlikte, yüksek dereceli karaciğer ve dalak hasarına yaklaşım halen tartışmalıdır. Bu çalışmanın amacı; yüksek dereceli karaciğer ve dalak hasarı olan hastalara nonoperatif tedavi yaklaşımıyla ilgili tecrübelerimizi sunmaktır.

GEREÇ VE YÖNTEM: Ocak 2012-Ocak 2017 tarihleri arasında Marmara Üniversitesi Hastanesi Acil Servisine başvuran hastalardan künt karın travmasına bağlı karaciğer ve dalak hasarı nedeniyle kliniğimizde takip edilen hastalar çalışmaya alındı. Hastaların yaş, cinsiyet, travma şekli, organ hasarının derecesi, eşlik eden organ hasarı, yoğun bakımda ve hastanede kalış süresi, transfüzyon ihtiyacı olması, tedavi yöntemi (operatif-nonoperatif) şeklinde olan verileri geriye dönük olarak analiz edildi. Grade I, II, III derece olan organ hasarları düşük dereceli olarak; grade IV, V olan organ hasarları ise yüksek dereceli olarak sınıflandırıldı.

BULGULAR: Acil servise başvuran 2800 çocuk travma olgusundan künt karın travmasına bağlı radyolojik görüntülemelerinde karaciğer ve dalak hasarı tespit edilip kliniğimizde yatıılan 88 hasta çalısmaya dahil edildi. Hastaların 4l'inde izole karaciğer hasarı, 39'unda izole dalak hasarı, 8'inde ise her iki organda hasar izlendi. Her iki organda hasar izlenen hastalarda yüksek dereceli hasarı olan organ hangisiyse o gruba dahil edildi. Yüksek dereceli (29), düşük dereceli (I7) karaciğer hasarı izlendi. Yüksek dereceli (2I), düşük dereceli (2I) dalak hasarı izlendi. Hastaların \%34'ünde (30 hastada) eşlik eden organ hasarı izlendi. Nonoperatif tedavi 83 hastaya (\%94) uygulanabildi; 5 hastaya (\%6) ise cerrahi uygulanması gerekti. Yüksek dereceli karaciğer hasarı olan hastalarda düşük dereceli karaciğer hasarı olanlara göre, hastanede yatış süresi, yoğun bakım ünitesinde (YBÜ) yatış süresi ve transfüzyon ihtiyacı anlamlı ölçüde yüksek bulundu (sırasıyla p; 0.00I, $0.001,<0.00$ I'dir). Yüksek dereceli karaciğer hasarı olan hastalarda düşük dereceli karaciğer hasarı olanlara göre daha fazla cerrahi yaklaşım uygulandı $(p=0.045)$. Yüksek ve düşük dereceli dalak yaralanmalarında her iki grup arasında yaş, cinsiyet, hastanede yatış süresi, YBÜ'de yatış süresi, transfüzyon ihtiyacı, eşlik eden organ hasarı açısından fark bulunmadı (sırasıyla p; $0.254,0.739,0.1$ I4, 0. I35, 0.057, 0.72 I). Benzer şekilde yüksek dereceli dalak hasarı olanlarla düşük dereceli dalak hasarı olanlar arasında nonoperatif veya operatif tedavi yaklaşımı açısından da fark izlenmedi $(p=0.488)$.

TARTIŞMA: Yüksek dereceli künt karaciğer ve dalak hasarı olan hastalarda nonoperatif tedavi uygulanabilir bir yöntemdir. Ancak yüksek dereceli karaciğer hasarı olanlarda düşük dereceli karaciğer hasarı olanlara göre cerrahi tedaviye daha fazla başvurulabileceği dikkate alınmalıdır. Anahtar sözcükler: Dalak hasarı; karaciğer hasarı, künt batın travması; nonoperatif tedavi; pediatrik travma. 